\title{
Intense light pulses upset the sensory quality of meat products
}

\author{
Tomašević Igor ${ }^{l}$
}

A b s t r a c t: Intense light pulses (ILP) is a promising non-thermal preservation technology. Few data are reported about the impact of the treatment on sensory quality of meat and meat products. Evaluation of the impact of ILP on sensory quality of meat products was performed using five different types of meat products: cooked ham, Parisian sausage, Parma ham, fermented sausage and bacon. All the samples were treated with 1 and 5 light pulses (pulse duration of $300 \mu$ s and pulse intensity of $3.4 \mathrm{~J} / \mathrm{cm} 2$ ) at a rate of one pulse per 2 seconds. Changes in the sensory quality induced by intense light pulses were different and depended on type of meat product and ILP dose applied. The results for cooked meat products are not promising because ILP significantly deteriorated their sensory quality. Dry-cured meat product, Parma ham and bacon, showed greater sensory resistance to the impact of ILP than examined cooked meat products. Fermented sausage was least affected by ILP of all the meat products investigated. Pulsed light lightened cooked ham after the higher treatment was applied while the lightness of Parisian sausage remained unaffected by the treatment. The a* value significantly decreased only after the 5-pulses treatment in Parma ham, fermented sausage and bacon while the $b^{*}$ value changed significantly (increased) only in bacon.

Key words: intense light pulses, meat products, sensory quality, color.

\section{Introduction}

Recent developments among consumers regarding the demand for fresh, minimally processed foods with a preferably long shelf life has resulted in emerging research into new non-thermal technologies to ensure appropriate preservation and safety of treated foodstuffs (Rowan et al.). Intense light pulses (ILP) are today recognized as an emerging non-thermal technology for the rapid inactivation of pathogenic and spoilage microorganisms in food.

ILP can inactivate pathogenic and spoilage microorganisms in a short time. It is a method of food preservation that involves the use of intense and short duration pulses of broad-spectrum white light. Each pulse, or flash of light lasts only a few hundred millionths of a second. The intensity of each pulse of light is cca. 20.000 times the intensity of sunlight at sea level (Ozer and Demirci, 2006).
Most of the literature concerning the application of ILP for the preservation of foods mainly deals with microbiological inactivation and few data are reported on sensory analysis (Hierro et al., 2011). So far and to the best of our knowledge, it has been examined on beef and tuna (Hierro et al., 2012), cooked ham and bologna (Hierro et al., 2011), salchichon and loin (Ganan et al., 2013) and chicken (Paskeviciute et al., 2011). Colorimetric analysis of the ILP-treated flat fish, salmon and shrimp (Cheigh et al., 2013), sliced ham (Wambura and Verghese, 2011), chicken (Keklik et al., 2010) and chicken frankfurters (Keklik et al., 2009) have been also previously reported.

The aim of this study was to systematically evaluate the effect of intense light pulses (ILP) on sensory quality of 5 different types of meat products. Since the meat purchasing decisions are influenced by colour more than any other quality factor,

Acknowledgements: The data presented in this paper are an integral part of the $\mathrm{PhD}$ research of dr Igor Tomašević completed at Department of Food Safety and Food Quality, Ghent University, Belgium and funded by BASILEUS PROJECT-EM ECW programme approved by European Commission. All the help, guidance and support received from the colleagues at the University of Ghent, Belgium as well as the loan of the equipment from Claranor, France is gratefully acknowledged. 
because consumers use discoloration as an indicator of freshness and wholesomeness (Mancini and Hunt, 2005), special attention in our investigation was paid to the effect of ILP on the color of meat products.

\section{Material and methods}

\section{Samples preparation}

Five meat products: cooked ham, Parisian sausage, Parma ham, fermented sausage and bacon, were used in this study. All of the samples used were purchased from a local retailer and kept refrigerated at $2 \pm 2{ }^{\circ} \mathrm{C}$ until treated. Meat products slices were sampled as purchased.

\section{ILP equipment and treatment}

The ILP treatments were performed using a laboratory-scale batch-fed pulsed-light system unit: Tecum - Mobile Decontamination Unit (Claranor, Manosque - France). Light pulses with duration of $300 \mu \mathrm{s}$ and pulse intensity of $3.4 \mathrm{~J} / \mathrm{cm}^{2}$, measured with SOLO 2 - Power and Energy Meter (Gentec
Electro-Optics, Inc., Quebec, Canada), were generated by four $20 \mathrm{~cm}$ cylindrical Xenon flash lamps (Flashlamps Verre \& Quartz, Bondy, France), with an input voltage of $3000 \mathrm{~V}$. The spectral intensity distribution of the light, as reported by Claranor, is shown in Figure 1. The samples were ILP-treated with 1 pulse (1P) and 5 pulses $(5 \mathrm{P})$ at a rate of one pulse per 2 seconds, respectively. During treatments, samples were placed in the system unit at a distance of $6 \mathrm{~cm}$ from the top and bottom lamps, and $10 \mathrm{~cm}$ from the left-hand and right-hand lamps. No treatment was applied to the control groups of samples.

\section{Sensory Analyses}

Sensory evaluation was performed by a professional panel of eight panelists, members of the Department of Food Safety and Food QualityUniversity of Ghent, Belgium and of the Animal Source Food Technology Department-University of Belgrade, Serbia. The panel was trained according to international standards (ISO, 1993) and additionally trained for three days in the sensory assessment of meat and meat products by a panel leader with over $2,000 \mathrm{~h}$ of sensory testing experience of meat

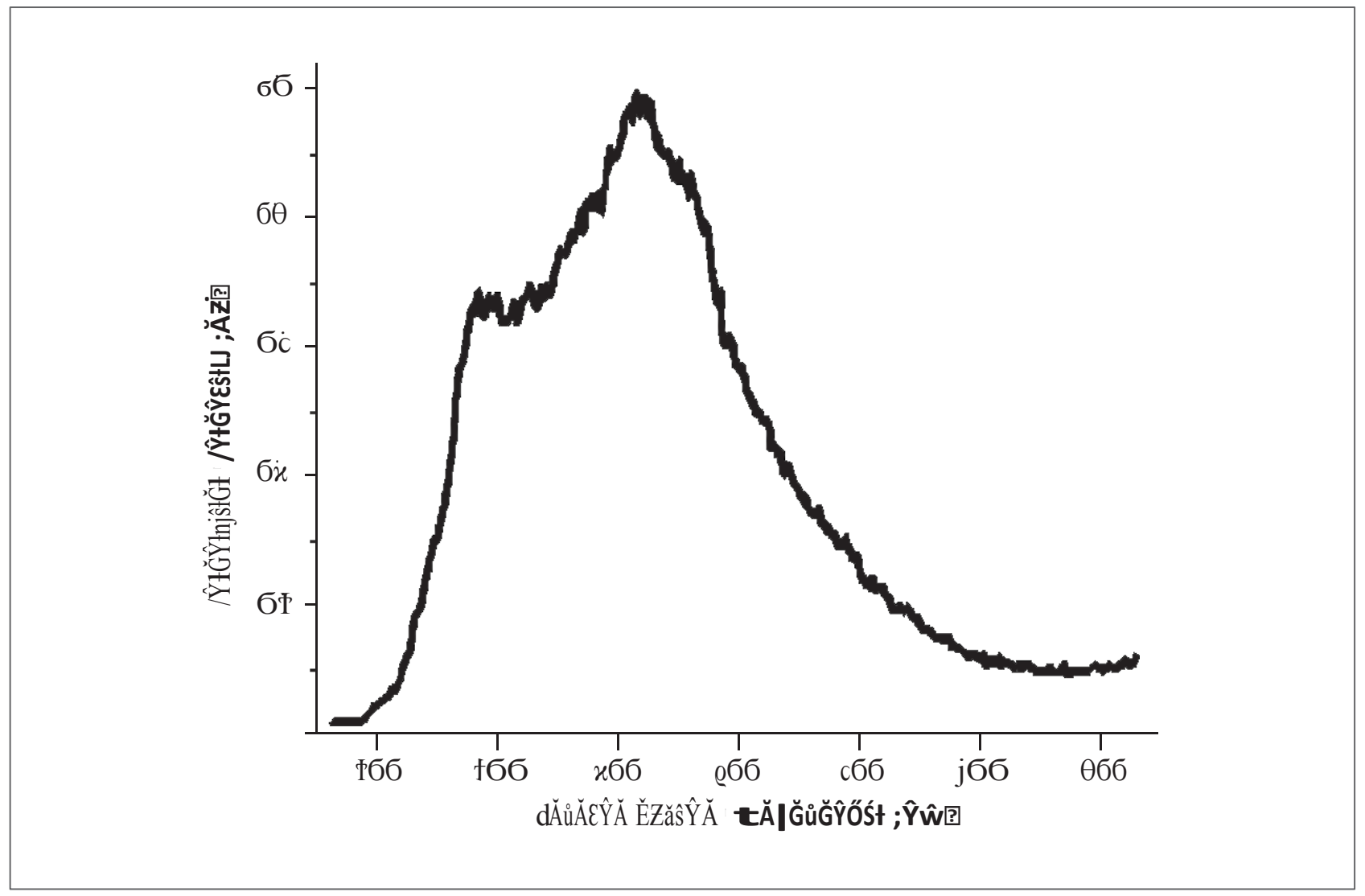

Graph 1. Spectral distribution of the xenon lamp used (Source: Claranor, France)

Grafik 1. Spektralna distribucija ksenonovih lampi uređaja TECUM-Claranor 
Table 1. Selected sensory attributes of the samples assessed using the 5 - point scale, with corresponding coefficients of importance (CI)

Tabela1. Odabrana senzorna svojstva i odgovarajući koeficijenti važnosti (KV) korišćeni prilikom ocenjivanja metodom korigovanog petobalnog bod sistema

\begin{tabular}{ccc}
\hline $\begin{array}{c}\text { Meat products/ } \\
\text { Proizvodi od mesa: }\end{array}$ & $\begin{array}{c}\text { Cooked ham, Parisian } \\
\text { sausage, Bacon/ } \\
\text { Kuvana šunka, Pariska } \\
\text { kobasica, Slanina }\end{array}$ & $\begin{array}{c}\text { Parma ham } \\
\text { Fermented sausage/ } \\
\text { Parma šunka, } \\
\text { Fermentisana kobasica }\end{array}$ \\
\hline Attribute/Svojstvo & $(\mathrm{CI}) /(\mathrm{KV})$ & $(\mathrm{CI}) /(\mathrm{KV})$ \\
\hline Appearance/Izgled & 4 & 4 \\
Color/Boja & 5 & 4 \\
Odor \& Taste/Miris \& Ukus & 7 & 8 \\
Texture\&Juiciness/Tekstura \& Sočnost & 4 & 4 \\
\hline
\end{tabular}

and meat products. The samples used in the additional training were over-treated with ILP (about 30 pulses per sample) and presented to the panelists in order to become acquainted with the impact of the treatment on a sample sensory profile. Each sample was identified by a three digit random code written on the serving plate.

The analyses were performed between meals. In all tests unsalted crackers and water were used to rinse the mouth between samples, which were presented about $10 \mathrm{~min}$ apart. Continual monitoring and investigation for any fatigue effect of individual results was performed to ensure satisfactory performance. Sensory tests were performed in a controlled sensory analysis laboratory (Food Safety and Food Quality Department/University of Ghent - Belgium) built in accordance to the general guidance for the design of test rooms intended for the sensory analysis of products $(I S O, 2007)$ with individual booths equipped with computer terminals and provided with red light to mask any differences in color when needed.

\section{Five-Point-Scale Scoring Method}

The test was carried out as described by Tomic et al. (2008) with slight modifications. Selected sensory attributes (Table 1) were assessed using the 5-point scale with the following descriptions: $5=$ (excellent, typical quality, without visible defects $) ; 4=$ (good quality, with minimal visible defects); 3 = (neither good nor poor quality, still can be used for its intended purpose); 2 = (poor quality, reworked could be used for its intended purpose); and $1=$ (unacceptable, extremely poor quality, cannot be used for its intended purpose), with ability of giving semi scores $(4.5,3.5,2.5$ and 1.5). Scores given to each of assessed attributes were corrected by corresponding coefficients of importance (Table 1).

Coefficients of importance (CI) show the relative importance of a single sensory attribute to the total sensory quality. Sum of all CIs is arranged to be 20 , and in that way the sum of corrected scores gives the ,percentage of total sensory quality” in a given situation. Dividing the total value by the sum of CI gives the ,pondered average value of total sensory quality". A section in the score card was included for panelists to leave their comments.

\section{Instrumental color measurement}

Instrumental color readings of samples were measured using Konica Minolta spectrophotometer CM-2500d (Konica Minolta, Osaka, Japan), operating in the CIE L*a*b* color space. The L* (lightness), $a^{*}$ (redness) and $b^{*}$ (yellowness) values (a single repetition) were determined from the mean of 10 random readings on the surface of each sample, using $\mathrm{D}_{65}$ illuminant and $10^{\circ}$ standard observer. The measurement was repeated in triplicate $(n=3)$ and the values averaged. The instrument was calibrated with a white calibration tile and black calibration box. Data acquisition was performed using the Spectramagic NX color data software, version 1.52 (Osaka, Japan).

\section{Statistical analysis}

Data entry and decoding were $100 \%$ verified. A one-way ANOVA was conducted to compare the results of the different assays, using SPSS Statistics 17.0 (Chicago, Illinois, USA) data analysis software. An alpha level of $p<0.05$ was used to determine significance. 


\section{Results and discussion}

\section{Five-Point-Scale Scoring Method}

The 5 - pulses treatment resulted in significant quality degradation in both ready-to-eat cooked meat products evaluated. The sensory quality of Parisian sausage and cooked ham deteriorated after the 5 - pulses treatment to such an extent that they were assessed as unacceptable products (Table 2). It was also observed that after the 1-pulse treatment the color of cooked ham slices equalized with the color of untreated samples and stabilized in the next 3-5 minutes, while the brownish color of 5 pulses treated cooked ham samples remained. Our findings are contrary to results previously reported by Hierro et al. (2011) where the testing panelists did not find significant differences $(p<0.01)$ in any of the parameters evaluated among pulsed and non-pulsed ham slices. The only similarity to our investigation of ready-to-eat cooked meat products, can be found in their results for bologna where the sensory test reflected differences $(\mathrm{p}<0.01)$ for odor and flavor in the samples treated with fluences of $4.2 \mathrm{~J} / \mathrm{cm}^{2}$ or higher, while appearance and color only differed in the slices pulsed with $8.4 \mathrm{~J} / \mathrm{cm}^{2}$.

Dry-cured meat product, Parma ham and bacon, showed a greater resistance to the impacts of ILP than examined cooked meat products. There were no statistically significant differences $(p>0.05)$ in

Table 2. Sensory evaluation scores (mean \pm SD) for 5 - Point - Scale Scoring test of the ILP treated meat products

Tabela 2. Srednje vrednosti senzornih ocena (korigovani petobalni bod sistem) proizvoda od mesa pre i posle ILP tretmana

\begin{tabular}{|c|c|c|c|c|c|c|}
\hline & & $\begin{array}{l}\text { Cooked Ham/ } \\
\text { Kuvana šunka }\end{array}$ & $\begin{array}{c}\text { Parisian } \\
\text { Sausage/ } \\
\text { Pariska } \\
\text { kobasica }\end{array}$ & $\begin{array}{l}\text { Parma Ham/ } \\
\text { Parma šunka }\end{array}$ & Bacon/ Slanina & $\begin{array}{l}\text { Fermented } \\
\text { Sausage/ } \\
\text { Fermentisana } \\
\text { kobasica }\end{array}$ \\
\hline \multirow{5}{*}{ 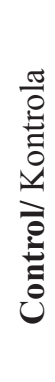 } & Appearance/ Izgled & $3.8 \pm 0.3 \mathrm{a}$ & $4.4 \pm 0.2 \mathrm{a}$ & $4.9 \pm 0.2$ & $4.9 \pm 0.2$ & $4.6 \pm 0.2$ \\
\hline & Color/ Boja & $3.9 \pm 0.2 \mathrm{a}$ & $4.9 \pm 0.2 \mathrm{a}$ & $4.9 \pm 0.2$ & $4.9 \pm 0.2 \mathrm{a}$ & $4.9 \pm 0.2$ \\
\hline & $\begin{array}{l}\text { Odor\&Taste/ } \\
\text { Miris \& Ukus }\end{array}$ & $3.6 \pm 0.2 \mathrm{a}$ & $4.4 \pm 0.2 \mathrm{a}$ & $4.4 \pm 0.2 \mathrm{a}$ & $4.4 \pm 0.2 \mathrm{a}$ & $4.4 \pm 0.1$ \\
\hline & $\begin{array}{l}\text { Texture\&Juiciness/ } \\
\text { Tekstura \& Sočnost }\end{array}$ & $3.9 \pm 0.2 \mathrm{a}$ & $4.4 \pm 0.2 \mathrm{a}$ & $4.4 \pm 0.2 \mathrm{a}$ & $4.4 \pm 0.2 \mathrm{a}$ & $4.4 \pm 0.2 \mathrm{a}$ \\
\hline & $\begin{array}{l}\text { Total score/ } \\
\text { Ukupna ocena }\end{array}$ & $3.8 \pm 0.1 \mathrm{a}$ & $4.5 \pm 0.2 \mathrm{a}$ & $4.6 \pm 0.2 \mathrm{a}$ & $4.6 \pm 0.2 \mathrm{a}$ & $4.5 \pm 0.2$ \\
\hline \multirow{5}{*}{ 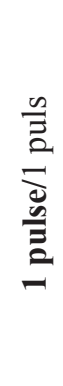 } & Appearance/Izgled & $3.3 \pm 0.3 b$ & $4.0 \pm 0.4 \mathrm{a}$ & $4.9 \pm 0.2$ & $4.9 \pm 0.2$ & $4.6 \pm 0.2$ \\
\hline & Color/Boja & $3.4 \pm 0.2 b$ & $4.4 \pm 0.2 b$ & $4.9 \pm 0.2$ & $4.9 \pm 0.2 \mathrm{a}$ & $4.8 \pm 0.2$ \\
\hline & $\begin{array}{l}\text { Odor\&Taste/ } \\
\text { Miris \& Ukus }\end{array}$ & $2.5 \pm 0.4 b$ & $4.0 \pm 0.4 \mathrm{a}$ & $4.0 \pm 0.4 \mathrm{a}$ & $3.9 \pm 0.2 b$ & $4.2 \pm 0.1$ \\
\hline & $\begin{array}{l}\text { Texture\&Juiciness/ } \\
\text { Tekstura \& Sočnost }\end{array}$ & $3.5 \pm 0.4 \mathrm{a}$ & $3.9 \pm 0.2 b$ & $4.1 \pm 0.2 \mathrm{a}$ & $4.1 \pm 0.2 \mathrm{a}, \mathrm{b}$ & $4.2 \pm 0.2 \mathrm{a}, \mathrm{b}$ \\
\hline & $\begin{array}{l}\text { Total score/ } \\
\text { Ukupna ocena }\end{array}$ & $3.1 \pm 0.2 b$ & $4.0 \pm 0.3 \mathrm{~b}$ & $4.4 \pm 0.2 \mathrm{a}$ & $4.4 \pm 0.2 \mathrm{a}$ & $4.4 \pm 0.2$ \\
\hline \multirow{5}{*}{ 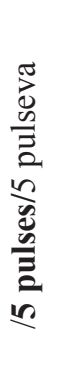 } & Appearance/Izgled & $2.9 \pm 0.2 b$ & $1.5 \pm 0.7 b$ & $4.8 \pm 0.3$ & $4.9 \pm 0.2$ & $4.3 \pm 0.1$ \\
\hline & Color/Boja & $1.6 \pm 0.2 \mathrm{c}$ & $1.2 \pm 0.3 \mathrm{c}$ & $4.7 \pm 0.3$ & $4.4 \pm 0.2 \mathrm{~b}$ & $4.7 \pm 0.2$ \\
\hline & $\begin{array}{l}\text { Odor\&Taste/ } \\
\text { Miris \& Ukus }\end{array}$ & $1.1 \pm 0.2 \mathrm{c}$ & $1.1 \pm 0.2 \mathrm{~b}$ & $2.6 \pm 0.2 b$ & $3.1 \pm 0.2 \mathrm{c}$ & $4.1 \pm 0.1$ \\
\hline & $\begin{array}{l}\text { Texture\&Juiciness/ } \\
\text { Tekstura \& Sočnost }\end{array}$ & $1.4 \pm 0.2 b$ & $1.6 \pm 0.2 \mathrm{c}$ & $3.6 \pm 0.2 \mathrm{~b}$ & $3.7 \pm 0.3 \mathrm{~b}$ & $3.9 \pm 0.2 \mathrm{~b}$ \\
\hline & $\begin{array}{l}\text { Total score/ } \\
\text { Ukupna ocena }\end{array}$ & $1.6 \pm 0.2 \mathrm{c}$ & $1.3 \pm 0.2 \mathrm{c}$ & $3.7 \pm 0.2 b$ & $3.9 \pm 0.2 b$ & $4.2 \pm 0.2$ \\
\hline
\end{tabular}

Legend/Legenda/a,b,c Values in the same column with different letter are significantly different $(\mathrm{p}<0.05)^{/ \mathrm{a}, \mathrm{b}, \mathrm{c}}$ Vrednosti $\mathrm{u}$ istoj koloni sa različitom slovnom oznakom su statistički značajno različite $(\mathrm{p}<0.05)$ 
Table 3. Instrumental color values (mean \pm SD) of the ILP treated meat products

Tabela 3. Srednje vrednosti instrumentalnih parametara boje proizvoda od mesa pre i posle ILP tretmana

\begin{tabular}{|c|c|c|c|c|c|c|}
\hline \multirow[b]{4}{*}{$\breve{U}$} & & $\begin{array}{l}\text { Cooked ham/ } \\
\text { Kuvana šunka }\end{array}$ & $\begin{array}{l}\text { Parisian Sausage/ } \\
\text { Pariska kobasica }\end{array}$ & $\begin{array}{l}\text { Parma ham/ } \\
\text { Parma šunka }\end{array}$ & $\begin{array}{l}\text { Fermented sausage/ } \\
\text { Fermentisana kobasica }\end{array}$ & Slanina \\
\hline & $\mathrm{L}^{*}$ & $62.0 \pm 0.6 \mathrm{a}$ & $68.0 \pm 0.1$ & $54.8 \pm 0.2 \mathrm{a}$ & $47.0 \pm 0.2$ & $58.3 \pm 0.9$ \\
\hline & $a^{*}$ & $12.7 \pm 0.2 \mathrm{a}$ & $11.8 \pm 0.3 \mathrm{a}$ & $22.2 \pm 0.3 \mathrm{a}$ & $18.1 \pm 1.1 \mathrm{a}$ & $12.0 \pm 0.4 \mathrm{a}$ \\
\hline & $b^{*}$ & $15.6 \pm 0.7 \mathrm{a}$ & $13.3 \pm 0.2 \mathrm{a}$ & $31.1 \pm 0.5$ & $10.1 \pm 0.2$ & $16.2 \pm 0.4 \mathrm{a}$ \\
\hline \multirow{3}{*}{ 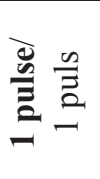 } & $\mathrm{L}^{*}$ & $62.8 \pm 0.5 \mathrm{a}$ & $67.5 \pm 0.5$ & $54.9 \pm 0.3 \mathrm{a}$ & $47.5 \pm 0.4$ & $57.6 \pm 0.4$ \\
\hline & $a^{*}$ & $11.5 \pm 0.3 b$ & $10.5 \pm 0.2 b$ & $20.6 \pm 0.4 b$ & $17.5 \pm 0.7 \mathrm{a}$ & $11.1 \pm 0.4 b$ \\
\hline & $b^{*}$ & $16.1 \pm 0.7 \mathrm{a}$ & $15.1 \pm 0.2 \mathrm{~b}$ & $31.3 \pm 0.5$ & $10.1 \pm 0.4$ & $17.6 \pm 0.4 \mathrm{~b}$ \\
\hline \multirow{3}{*}{ 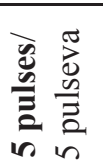 } & $\mathrm{L}^{*}$ & $64.5 \pm 1.0 \mathrm{~b}$ & $68.2 \pm 0.8$ & $53.0 \pm 0.3 \mathrm{~b}$ & $47.0 \pm 0.3$ & $57.3 \pm 1.2$ \\
\hline & $a^{*}$ & $9.2 \pm 1.0 \mathrm{c}$ & $8.6 \pm 0.6 c$ & $20.5 \pm 0.3 b$ & $15.3 \pm 0.4 b$ & $8.9 \pm 0.1 \mathrm{c}$ \\
\hline & $b^{*}$ & $17.4 \pm 1.0 \mathrm{~b}$ & $16.5 \pm 0.2 \mathrm{c}$ & $31.3 \pm 0.5$ & $10.5 \pm 0.2$ & $18.5 \pm 0.3 b$ \\
\hline
\end{tabular}

Legend/Legenda: ${ }^{a, b, c}$ Values in the same column with different letter are significantly different $(\mathrm{p}<0.05) \mathrm{L}^{*}($ lightness), a* (redness) and $b^{*}$ (yellowness)/a,b,c Vrednosti $u$ istoj koloni sa različitom slovnom oznakom su statistički značajno različite $(p<0.05)$ L* (svetloća), a* (udeo crvene boje) i b* (udeo žute boje)

any of the attributes evaluated between 1 pulse treated and untreated samples of Parma ham (Table 3). In the case of bacon, the same treatment caused significant difference only in odor, although assessors noted that the odor of both, treated and control bacon samples, was not so pronounced. When the higher fluence of $17 \mathrm{~J} / \mathrm{cm}^{2}$ (5 - pulses treatment) was applied to Parma ham and bacon their odor and taste significantly decreased $(\mathrm{p}<0.05)$ to the level of neither good nor poor, as assessed by the panelist. The changes in their texture and juiciness followed. This is in agreement with the previously observed variations in dry cured loin right after the ILP treatment of $11.9 \mathrm{~J} / \mathrm{cm}^{2}$ when odor and flavor significantly decreased (Ganan et al., 2013), also.

The sensory quality of 1 pulse treated fermented sausage was not significantly different to the control sample (Table 2) which is in concurrence with the findings of Ganan et al. (2013) where no significant differences $(\mathrm{p}>0.05)$ were observed in salchichón treated with different fluences, also. When the fermented sausage was exposed to 5 - pulses treatment only the texture and juiciness were significantly affected. It was already observed that one of the main ILP disadvantages is that heat can be generated as a side effect, which can cause dehydration (Oms-Oliu et al., 2010) that caused slight deterioration of the fermented sausage juiciness, in our case.

\section{Instrumental color measurement}

Pulsed light lightened cooked ham after the higher treatment was applied (Table 3). The a* value gradually decreased as fluence increased while only the highest fluences significantly affected the $b^{*}$ value, same way it did in the experiments of $E$. Hierro et al. (2011). The lightness of Parisian sausage remained unaffected while redness and yellowness suffered significantly with observed difference among the fluences assayed. The significant increase in $b^{*}$ values of cooked ham after the ILP treatment was previously reported (Wambura and Verghese, 2011) as well as other cooked-meat products like bologna (Hierro et al., 2011) and chicken frankfurters (Keklik et al., 2009).

In Parma ham, lightness $\left(\mathrm{L}^{*}\right)$ was significantly lower in samples treated with $17 \mathrm{~J} / \mathrm{cm}^{2}(5$ pulses) compared to control and samples treated with 3.4 $\mathrm{J} / \mathrm{cm}^{2}$ (1 pulse) while in fermented sausage and bacon it remained unaffected by the ILP (Table 3). The lightness of dry-cured loin also endured while it was significantly higher in salchichón (fermented sausage) in samples treated with $11.9 \mathrm{~J} / \mathrm{cm}^{2}$ as reported by (Ganan et al., 2013). The a* value significantly decreased after the 5-pulses treatment in Parma ham, fermented sausage and bacon while the $b^{*}$ value has significantly changed (increased) only in bacon. It has been reported that when cured meat products are exposed to light, discoloration appears as a decrease in $a^{*}$ values and an increase in $b^{*}$ values, with or without a change in $\mathrm{L}^{*}$ (Hunt et al., 1991). 


\section{Conclusion}

Our study indicated that the changes in sensory quality induced by intense light pulses are different and depended on type of meat product and ILP dose applied. The results for cooked meat products are not promising because ILP significantly deteriorated their quality. ILP caused fewer changes in the sensory properties of dry cured then in cooked meat products. Fermented sausage was least affected by ILP of all the meat products.

\section{References}

Cheigh C. I., Hwang H. J., Chung M. S., 2013. Intense pulsed light (IPL) and UV-C treatments for inactivating Listeria monocytogenes on solid medium and seafoods. Food Research International, 54,1, 745-752.

Ganan M., Hierro E., Hospital X. F., Barroso E., Fernandez M., 2013. Use of pulsed light to increase the safety of ready-to-eat cured meat products. Food Control, 32, 2, 512-517.

Hierro E., Barroso E., de la Hoz L., Ordonez J. A., Manzano S., Fernandez M., 2011. Efficacy of pulsed light for shelf-life extension and inactivation of Listeria monocytogenes on ready-to-eat cooked meat products. Innovative Food Science \& Emerging Technologies, 12, 3, 275-281.

Hierro E., Ganan M., Barroso E., Fernández M., 2012. Pulsed light treatment for the inactivation of selected pathogens and the shelf-life extension of beef and tuna carpaccio. International Journal of Food Microbiology, 158, 1, 42-48.

Hunt M. C., Acton J. C., Benedict R. C., Calkins C. R., Conforth D. P., Jeremiah L. E., 1991. American Meat Science Association Committee on Guidelines for Meat Color Evaluation. National Live Stock and Meat Board. Chicago.

ISO, 1993. ISO 8586-1:1993 Sensory analysis - General guidance for the selection, training and monitoring of assessors Part 1: Selected assessors. Geneva, Switzerland.

ISO, 2007. ISO 8589:2007 Sensory analysis - General guidance for the design of test rooms. Geneva, Switzerland.

Keklik N. M., Demirci A., Puri V. M., 2009. Inactivation of Listeria monocytogeneson Unpackaged and VacuumPackaged Chicken Frankfurters Using Pulsed UV-Light. Journal of Food Science, 74, 8, M431-M439.
Keklik N. M., Demirci A., Puri V. M., 2010. Decontamination of unpackaged and vacuum-packaged boneless chicken breast with pulsed ultraviolet light. Poultry Science, 89, 3, 570-581.

Mancini R. A., Hunt M. C., 2005. Current research in meat color. Meat Science, 71, 1, 100-121.

Oms-Oliu G., Martín-Belloso O., Soliva-Fortuny R., 2010. Pulsed Light Treatments for Food Preservation-A Review. Food and Bioprocess Technology, 3, 1, 13-23.

Ozer N. P., Demirci A., 2006. Inactivation of Escherichia coli O157 : H7 and Listeria monocytogenes inoculated on raw salmon fillets by pulsed UV-light treatment. International Journal of Food Science and Technology, 41, 4, 354-360.

Paskeviciute E., Buchovec I., Luksiene Z., 2011. High-power pulsed light for decontamination of chicken from food pathogens: a study on antimicrobal efficiency and organolpetic properties. Journal of Food Safety, 31, 1, 61-68.

Rowan N. J., Valdramidis V. P., Gómez-López V. M., 2015. A review of quantitative methods to describe efficacy of pulsed light generated inactivation data that embraces the occurrence of viable but non culturable state microorganisms. Trends in Food Science \& Technology, 44, 79-92.

Tomic N., Tomasevic I., Radovanovic R., Rajkovic A., 2008. "Uzice Beef Prshuta": Influence of different salting processes on sensory properties. Journal of Muscle Foods, 19, 3, 237-246.

Wambura P., Verghese M., 2011. Effect of pulsed ultraviolet light on quality of sliced ham. LWT - Food Science and Technology, 44, 10, 2173-2179. 


\title{
Uticaj intezivnih svetlosnih pulseva na senzorni kvalitet proizvoda od mesa
}

\author{
Tomašević Igor
}

R e z i m e: Ispitivan je uticaj intenzivnih svetlosnih pulseva (ISP) na senzorni kvalitet proizvoda od mesa koristeći pet različitih tipova proizvoda od mesa: kuvane šunke, pariske kobasice, Parma šunke, fermentisane kobasice i slanine. Svi uzorci tretirani su sa $1 i$ 5 svetlosnih pulseva (dužina trajanja pulsa $300 \mu$ s i intenzitet pulsa 3,4 J/cm2) u interval od jednog pulsa na svake 2 sekunde. Promene senzornog kvaliteta nastale dejstvom intenzivnih svetlosnih pulseva su se razlikovale i bile su zavisne od vrste proizvoda od mesa i jačine primenjenog tretmana. Rezultati vezani za barene proizvode od mesa nisu obećavajući s obzirom da je ISP značajno umanjio njihov senzorni kvalitet. Suvi salamureni proizvodi od mesa, Parma šunka i slanina, pokazali su veću senzornu postojanost na dejstvo ISP u odnosu na barene proizvode od mesa. Fermentisana kobasica je pretrpela najmanje senzorne promene od svih ispitivanih proizvoda od mesa. IPS je posvetleo kuvanu šunku nakon primene jačeg tretmana dok je svetloća pariske kobasice ostala nepromenjena. Vrednost $a^{*}$ značajno je opala tek nakon dejstva 5 pulseva kod Parma šunke, fermentisane kobasice i slanine dok je b* vrednost značajno promenjena (porasla) samo kod slanine.

Ključne reči: intenzivni svetlosni pulsevi, proizvodi od mesa, senzorni kvalitet, boja.

Paper received: 29.4 .2015 .

Paper corrected: 9.06.2015.

Paper accepted: 10.06.2015. 